\title{
"Testing for explosive bubbles in the South African-US exchange rate using the sequential ADF procedures"
}

\begin{tabular}{ll} 
AUTHORS & $\begin{array}{l}\text { Uchenna Elike } \\
\text { Emmanuel Anoruo }\end{array}$ \\
ARTICLE INFO & $\begin{array}{l}\text { Uchenna Elike and Emmanuel Anoruo (2017). Testing for explosive bubbles in } \\
\text { the South African-US exchange rate using the sequential ADF procedures. } \\
\text { Banks and Bank Systems, 12(1-1), 105-112. doi:10.21511/bbs.12(1-1).2017.02 }\end{array}$ \\
\hline DOI & http://dx.doi.org/10.21511/bbs.12(1-1).2017.02 \\
\hline RELEASED ON & Tuesday, 25 April 2017 \\
\hline RECEIVED ON & Monday, 23 January 2017 \\
\hline ACCEPTED ON & Wednesday, 15 February 2017 \\
\hline LICENSE & $\begin{array}{l}\text { T(c) EY-No } \\
\text { Inis work is licensed under a Creative Commons Attribution-NonCommercial } 4.0\end{array}$ \\
\hline JOURNAL & "Banks and Bank Systems" \\
\hline ISSN PRINT & $1816-7403$ \\
\hline ISSN ONLINE & $1991-7074$ \\
\hline PUBLISHER & LLC “Consulting Publishing Company “Business Perspectives" \\
\hline FOUNDER & LLC "Consulting Publishing Company "Business Perspectives"
\end{tabular}

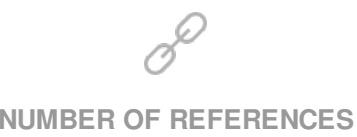

25
NUMBER OF FIGURES

3
NUMBER OF TABLES

4

(C) The author(s) 2023. This publication is an open access article. 
Uchenna Elike (USA), Emmanuel Anoruo (USA)

\title{
Testing for explosive bubbles in the South African-US exchange rate using the sequential ADF procedures
}

\begin{abstract}
This paper tests for the existence of speculative bubbles in the South African-US exchange rate using the sequential ADF procedures. In particular, the paper uses the SADF and GSADF right-tailed unit root tests to explore the existence of explosive bubbles in the South African-US exchange rate for the time period running from January1980 through July 2012. The results provide evidence in support of the existence of explosive bubbles in the nominal rand-dollar exchange rate, the real exchange rate of traded and non-traded goods. The explosive behavior exhibited by the South African rand-US dollar exchange rate can be interpreted as evidence of rational bubbles given that this behavior is driven by the fundamentals including relative prices of traded and non-traded goods.
\end{abstract}

Keywords: exchange rates, rational bubbles, sequential unit root test, traded goods, non-traded goods.

JEL Classification: F31, C12, C15, C22.

Received on: $23^{\text {th }}$ of January, 2017.

Accepted on: $15^{\text {th }}$ of February, 2017.

\section{Introduction}

The subject of rational bubbles continues to attract the attention of investors and policy makers alike. Early detection of speculative bubbles is important to investors, as it enables them to rebalance their portfolios in anticipation of the impending crash. For policy makers, a clear understanding of the existence and size of rational bubbles is crucial in order for them to formulate and implement appropriate strategies to mitigate speculative bubbles in the foreign exchange markets. According to Kindelberger and Aliber (2005) bubble is a sharp increase in asset prices whereby the initial increase generates expectations of further increases and, hence, attracting new buyers.

Economic theory has always postulated that exchange rates play crucial roles in determining international trade and, hence, economic growth. In their study, Edwards and Yeyati (2016) show that under flexible exchange rates, economies grow more rapidly than under fixed rates. In addition, they show that countries with rigid exchange rates experience more exacerbated effects from terms of trade. However, some studies have pointed out that since the introduction of flexible exchange rates, many national economies and markets have experienced increased volatility. Finance theory posits that there is a nexus between exchange rates, inflation and interest rate differentials, which contribute to the direction of capital and asset flows between countries, and, thus, determine asset prices. Therefore,

\footnotetext{
(c) Uchenna Elike, Emmanuel Anoruo, 2017.

Uchenna Elike, Ph.D., Department of Accounting and Finance, Alabama A\&M University, Normal, Alabama, USA.

Emmanuel Anoruo, Ph.D., Department of Accounting and Management Information Systems, Coppin State University, Baltimore, Maryland, USA.

This is an Open Access article, distributed under the terms of the Creative Commons Attribution-NonCommercial 4.0 International license, which permits re-use, distribution, and reproduction, provided the materials aren't used for commercial purposes and the original work is properly cited.
}

the fact that exchange rates can freely float, no doubt, increases speculation in asset prices, increasing volatility in the financial markets. According to Kindelberger and Aliber (2005), bubble is a sharp increase in asset prices whereby the initial increase generates expectations of further increases and, hence, attracting new buyers. The existence of rational bubbles suggests that nominal exchange rate and prices are not related in the long run. Traditional theory attributes fluctuations in real exchange rates to changes in the relative price of nontraded goods. Obstfeld and Rogoff (1996) suggest that the nominal exchange rate should be considered as an asset price

Given that the world's dominant currency is the US dollar and asset prices in the global markets are denominated in the dollar, it is no wonder that with such a linkage, many countries are not just susceptible to their own internal macroeconomic circumstances, but also to those of the United States. Thus, speculative bubbles in exchange rates drive global markets. For example, Zhang and Yao (2015) show how speculative bubbles had engulfed international crude oil futures. Moreover, many developing countries like to align their currencies to the US dollar in order to help them to build up foreign reserves and manage their current accounts. However, such moves leave their currencies very vulnerable to some unanticipated fluctuations in the US dollar. Odhiambo (2015) discovered that the South African rand experienced a "speculative attack" in the mid-1970s following sharp decline in the US dollar precipitated by fluctuations in the global foreign exchange markets.

Against these backdrops, this paper, therefore, explores the existence of multiple bubbles in the South AfricanUS exchange rate. South Africa provides an excellent avenue to investigate the issue of rational bubbles in the foreign exchange markets. The South African rand serves as a de facto currency for the Common Mone- 
tary Area (CMA), which includes Lesotho, Namibia and Swaziland. Like most developing countries, the South African economy has experienced fundamental exchange rate fluctuations in the past decades. South African authorities have attracted foreign capital by keeping interest rates high to ensure that the inflation rate is within the target range of 3-6\%. Sound macroeconomic policies and political stability portray South Africa as one of the most investor-friendly countries in the African continent since the 1990s. Odhiambo (2015) notes that the country is one of the most investor-friendly countries in Africa. These characteristics have combined to ensure sustained capital inflows, which have had an increased speculative volatility of the rand.

Most of the earlier studies on rational speculative bubbles were conducted using the standard cointegration tests such as those proposed by Johansen (1988), Johansen and Juselius (1990), which are designed to detect linear relationships. However, a number of studies in the literature, including Hsieh (1991) and Abhyankar et al. (1997), have shown that financial time series tend to exhibit nonlinear dependencies. To mitigate the weaknesses associated with the conventional tests, this study applies the supremum Augmented DickeyFuller (SADF) recursive test proposed by Phillips et al. (2011). The SADF test has the ability to detect exuberance in asset prices series, especially during inflationary phases. A drawback of the SADF recursive test is that it is mostly effective when there is a single bubble episode in the sample data. To overcome this weakness, Philips et al. (2013) developed the generalized sup Augmented Dickey-Fuller (GSADF) test, which is capable of detecting multiple bubbles that may exist within the same sample period. The application of the GSADF test enables the researcher to simultaneously account for both nonlinear structure and break mechanisms. Above all, the GSADF procedure is capable of detecting multiple bubbles in the financial time series of interest.

The results from the standard right-sided ADF test statistic suggest that there is no explosive bubble in the nominal South African - US exchange rate, the real exchange rate of traded and non-traded goods. In contrast, the results from the SADF and the GSADF tests provide evidence in support of the existence of explosive bubbles in the nominal rand-dollar exchange rate, the real exchange rate of traded and non-traded goods. The explosive behavior exhibited by the rand-dollar exchange rate can be interpreted as evidence of speculative bubble given that this behavior is driven by the relative prices of traded and non-traded goods. The empirical results from the present study indicate that multiple bubbles exist in the rand-dollar exchange rate.
The remainder of the paper is organized as follows. Following the present introduction, section 1 discusses the literature review. Section 2 presents the methodologies of the study. Section 3 describes the data and the summary statistics. Section 4 presents empirical results. Final section offers the conclusions of the study.

\section{Literature review}

The existence of speculative bubbles in financial markets has been extensively debated in the literature given its importance in financial economics. Earlier studies on this topic have produced mixed results. For instance, Jirasakuldech et al. (2006) using the integration and cointegration analyses examined the existence of rational speculative bubbles in the exchange rates of the British pound, the Canadian dollar, the Danish krone, the Japanese yen and the South African rand against the US dollar. They find that these bilateral exchanges have one order of integration and are also cointegrated with the US dollar. They concluded that these five exchange rates do not exhibit rational speculative bubbles. Bettendorf and Chen (2013) used the sequential unit root tests to investigate the existence of speculative bubbles in the sterling-dollar exchange rate. They find evidence of explosive behavior in the nominal sterling-dollar exchange rate. They, however, suggest that the finding of explosive behavior does not necessarily indicate the existence rational bubbles in the Sterling-dollar exchange rate, as the behavior could have been driven by the relative prices of traded goods. Jiang et al. (2015) used the generalized sup ADF (GSADF) unit root tests to examine the existence of bubbles in the nominal RMB-dollar exchange rates. They find evidence of explosive behavior in the nominal exchange rate. They find evidence of two bubbles; with the first bubble occurring during 2005-2006. The second bubble occurred in 2008 during the subprime crisis period. They maintain that the first bubble was neither determined by the relative prices of traded goods nor the relative price of non-traded goods. However, they suggest the second bubble was determined by the relative prices of traded goods, but not the relative price of nontraded goods.

Montasser et al. (2016) applied the right-tailed unit root (sup Augmented Dickey-Fuller (SADF) and generalized sup ADF) tests to the China-US exchange rate. They find evidence of an explosive behavior in the nominal exchange from 2005 onwards. They attribute the explosive behavior in the China-US exchange rate to differences in the relative prices of traded goods. $\mathrm{Wu}$ (1995) used the Kalman filter technique to estimate and test for stochastic bubbles in exchange rates between the US dollar and the British pound, the Japanese yen and the Deutsche mark. He failed to find evidence of speculative bubbles in both exchange rates. Betts and Kehoe (2006) examine the relationship between the United States' bilateral real exchange rate and the associated bilateral relative price of non- 
traded goods for five of its most important trade relationships. They find that this relation depends crucially on the choice of price series used to measure relative prices and on the choice of trade partner. The relation is stronger when the relative prices are measured using producer prices rather than consumer prices. The relation is stronger the more important is the trade relationship between the United States and a trade partner. Even in cases where there is a strong relation between the real exchange rate and the relative price of nontraded goods, however, a large fraction of real exchange rate fluctuations is due to deviations from the law of one price for traded goods. Engel (1999) investigates the extent to which changes in the relative prices of non-traded goods are responsible for fluctuations real exchange rates between the United States and other high-income countries. He finds that changes in relative prices of non-traded goods do not account for innovations in the United States real exchange rates. Woo (1987) using a portfolio-balance model find evidence of bubbles in foreign exchange markets. Similarly, West (1987) applied the volatility models and found that no evidence of bubbles in the foreign exchange markets. Evans (1986) using the nonparametric procedure examined the existence of speculative bubbles in the sterling-dollar exchange rate for the period 1981 through 1984. He found evidence of speculative bubbles in the sterling-dollar exchange rate.

\section{Methodology}

This paper tests for speculative bubbles by means of the Phillips et al. (2011b) recursive ADF tests including the SADF and GSADF. These procedures are capable of detecting periodically collapsing bubbles in the data period. The ADF unit root procedure is given by:

$$
\Delta y_{t}=\mu+\delta y_{t-1}+\sum_{j=1}^{j} \phi_{t} \Delta y_{t-j}+\varepsilon_{t} .
$$

In equation (1), y represents the variable of interest (in our case, exchange rate series $-\mathrm{s}_{\mathrm{t},}, \mathrm{s}_{\mathrm{t}}-f_{\mathrm{t}}^{\mathrm{N}}$ and $\left.\mathrm{s}_{\mathrm{t}}-f_{\mathrm{t}}^{\mathrm{N}}\right) . \mathrm{s}_{\mathrm{t}}$ is the logarithm of nominal exchange, $\mathrm{s}_{\mathrm{t}}-f_{\mathrm{t}}^{\mathrm{N}}$ is the logarithm of nominal exchange rate relative to nontraded goods and $\mathrm{s}_{\mathrm{t}}-f_{\mathrm{t}}^{\mathrm{N}}$ represents the logarithm of nominal exchange relative to traded goods. $\mathrm{E}\left(\varepsilon_{t}\right)=0$, and $\mathrm{E}\left(\varepsilon_{t}^{2}\right)=\sigma^{2}$. The standard null hypothesis of unit root tests is $\mathrm{H}_{0}: \delta=1$; while the right-tailed alternative hypothesis is $\mathrm{H}_{1}: \delta>1$ (explosive behavior). The right-tailed ADF statistic is calculated in multiple recursive regressions. Each sub-sample begins with initial observation, while the last observation is allowed to vary. Let $r_{1}$ represent the fraction starting point, while $r_{2}$ denotes the fraction of ending point of the sample. The sample window represented by $r_{w}=r_{2}-r_{1}$ can vary from the initial window size $r_{0}$ to the total sample. In the spirit of Phillips et al. (2011, 2013), a sequence of ADF tests are computed. The SADF statistic is based on the supremum value of the ADF statistic obtained from equation (1). The SADF procedure is given by:

$$
\mathrm{SADF} r 0=\sup _{\mathrm{r} 2 \in[\mathrm{r} 0,1]}\left\{\mathrm{ADF}_{\mathrm{r} 2}\right\} \text {. }
$$

They determine the existence of explosiveness in the series of interest, the test statistic obtained from the SADF procedure is compared with the right-tailed critical values obtained through simulations. Phillips et al. (2013) point out that even though the SADF test consistently determines the starting date of the first bubble in the event of two bubble alternatives, it can, however, fail to identify the second bubble. This suggests that in the presence of two bubbles, the second bubble may not be detected if it is dominated by the first one. Phillips et al. (2011) also introduced a rolling version of the SADF test, referred to as RADF. Under the RADF test, the starting window moves over the sample. In addition, the size of the starting window is fixed. This limits the power of the RADF test to detect potential bubbles.

To overcome the weaknesses associated with the SADF and RADF, Phillips et al. (2013) developed the 'generalized' sup ADF (GSADF) test as a dating mechanism. The GSADF diagnostic is also predicated on sequential right-tailed ADF tests. Unlike the SADF test, the diagnostic of the GSADF extends the sample sequence to a more flexible range. The GSADF test allows both the starting and ending points of the sample to vary over a feasible range of windows. Phillips et al. (2013) have shown that the moving sample GSADF diagnostic outperforms the SADF test based on an expanding sample size in detecting explosive behavior in multiple bubble episodes and seldom gives false alarms, even in relatively modest sample sizes. The reason is that the GSADF test covers more subsamples of the data. The generalized SADF test (GSADF) is able to detect potential multiple bubbles in the data and, thus, overcomes the weakness of the SADF test. The GSADF test based on:

$$
\mathrm{GSADF}_{\mathrm{r} 0}=\sup _{\mathrm{r} 2 \in[\mathrm{r} 0,1], \mathrm{r} 1 \in[0, \mathrm{r} 2-\mathrm{r} 0]}\left\{\mathrm{ADF}_{\mathrm{r} 1}^{\mathrm{r} 2}\right\} .
$$

For further details regarding the SADF and GSADF tests, interested readers can refer to Philips and $\mathrm{Yu}$ (2011), Philips et al. (2011), and Philips et al. (2013).

\section{Data and descriptive statistics}

The data consist of monthly observation on bilateral exchange rates between South Africa and the United States for the time period running from January 1980 through July 2012. The data on nominal exchange rates were obtained from the International Financial Statistics version 12, published by the World Bank. The nominal exchange rate series were 
converted to natural logarithms. Following Engel (1999), the ratio of the exchange rate to the traded goods fundamental is given by:

$s_{t}^{r}=s_{t}+\log \left(P P I_{t}^{*}\right)-\log \left(P P I_{t}\right)$,

where $s_{t}$ represents the logarithm of nominal rand/US dollar exchange rate, PPI is the producer price index and the asterisk represents the foreign counterpart. Rewriting equation (4) in exponential form yields:

$s_{t}^{r, N}=s_{t}+\log \left(P P I_{t}^{*}\right)-\log \left(P P I_{t}\right)+\log \left(C P I_{t}^{*}\right)-\log \left(C P I_{t}\right)$.

Equation (6) is rewritten in exponential form as follows:

$s_{t}^{r, T}=s_{t} \frac{P P I_{t}^{*}}{P P I_{t}} \frac{C P I_{t}^{*}}{C P I_{t}}$.

Equation (7) gives the ratio of overseas goods and services purchased by households scaled by the domestic goods and services purchased by households after adjusting for goods directly braded between the two countries. Therefore, equations (6) and (7) show the effect of non-traded goods on exchange rate.

Table 1 displays the descriptive statistics for the logarithm of rand-dollar nominal exchange rate, relative prices of traded and non-traded goods ratios.

Table 1. Descriptive statistics

\begin{tabular}{|l|c|c|c|}
\hline \multicolumn{1}{|c|}{ Statistic } & $\mathrm{S}_{\mathrm{t}}$ & $\mathrm{S}_{\mathrm{t}}-f_{\mathrm{t}}^{\mathrm{N}}$ & $\mathrm{S}_{\mathrm{t}}-f_{\mathrm{t}}^{\mathrm{T}}$ \\
\hline Mean & 6.58 & 6.56 & 7.07 \\
\hline Median & 6.07 & 6.07 & 6.30 \\
\hline Maximum & 15.36 & 15.41 & 15.20 \\
\hline Minimum & 0.94 & 0.80 & 2.66 \\
\hline Standard deviation & 4.07 & 4.12 & 3.51 \\
\hline Skewness & 0.21 & 0.21 & 0.36 \\
\hline Kurtosis & 1.73 & 1.73 & 1.81 \\
\hline Jarque-Bera & $29.46^{* * *}$ & $29.01^{\text {*** }}$ & $31.63^{\text {*** }}$ \\
\hline Probability & 0.00 & 0.00 & 0.00 \\
\hline Observations & 391 & 391 & 391 \\
\hline
\end{tabular}

*** indicates rejection of the normality assumption at the $1 \%$ significance level. $\mathrm{s}_{\mathrm{t}}=$ nominal exchange rate (rand per US dollar), $\mathrm{S}_{\mathrm{t}}-f_{\mathrm{t}}^{\mathrm{N}}$ and $_{\mathrm{S}_{\mathrm{t}}}-f_{\mathrm{t}}^{\mathrm{T}}$ represent the ratios of the exchange rate to the non-traded and traded goods fundamentals, respectively.

The mean values are 6.58, 6.57 and 7.07 percent, respectively, for $\mathrm{s}_{\mathrm{t},}, \mathrm{s}_{\mathrm{t}}-f_{\mathrm{t}}^{\mathrm{N}}$ and $\mathrm{s}_{\mathrm{t}}-f_{\mathrm{t}}^{\mathrm{T}}$. The relative price of non-traded goods ratio posted the highest standard deviation (4.12), while the relative price of traded goods (3.51) ratio documented the least. The nominal rand-dollar exchange rate posts a standard deviation of 4.07 and appears to be less volatile than the two relative price ratios. The standard deviations provide evidence that the $\mathrm{s}_{\mathrm{t}, \mathrm{S}_{\mathrm{t}}}-f_{\mathrm{t}}^{\mathrm{N}}$ and $\mathrm{s}_{\mathrm{t}}-f_{\mathrm{t}}^{\mathrm{T}}$ series display rich and volatile market dynamics. The JarqueBera statistics are 29.46, 29.01 and 31.63, respectively, $s_{t}^{r, T}=s_{t} \frac{P P I_{t}^{*}}{P P I_{t}} \cdot$

The second argument on the right hand side of equation (5) represents the ratio of prices received by overseas producers divided by the prices received by domestic producers. Essentially, equations (4) and (5) measure the direct relative effect of traded goods on exchange rate. In the spirit of Bettendorf and Chen (2013), the ratio of exchange rate to nontraded goods fundamental is derived as follows:

for $\mathrm{s}_{\mathrm{t}} \mathrm{s}_{\mathrm{t}}-f_{\mathrm{t}}^{\mathrm{N}}$ and $\mathrm{s}_{\mathrm{t}}-f_{\mathrm{t}}^{\mathrm{T}}$. These test statistics are statistically significant at the 1 percent level and suggest that the null hypothesis of normal distribution should be rejected. From the minimum and maximum statistics reported in Table 1, it can be surmised that the values of $\mathrm{s}_{\mathrm{t}}, \mathrm{s}_{\mathrm{t}}-f_{\mathrm{t}}^{\mathrm{T}}$ and $\mathrm{s}_{\mathrm{t}}-f_{\mathrm{t}}^{\mathrm{T}}$ fluctuated over the study period.

\section{Empirical results}

The study uses the right-tailed unit root test to examine the existence of speculative bubbles in rand-US dollar exchange rate. In particular, the tests are applied to the logarithm of the nominal exchange rate, the logarithms of the ratios of the relative prices of nontraded and traded goods. Tables 1 through 5 display the results from the ADF, SADF and GSADF tests for the natural logarithms of the monthly rand-dollar exchange rate $\left(\mathrm{s}_{\mathrm{t}}\right)$, relative price of traded goods ratio and the relative of nontraded goods ratio. Table 2 displays the ADF, SADF, RADF and GSADF test results for the logarithm of nominal exchange between South Africa and the United States.

Table 2. The ADF, SADF, RADF and GSADF tests for nominal exchange rate

\begin{tabular}{|l|c|c|c|c|}
\hline \multicolumn{1}{|c|}{ Test } & $\mathrm{s}_{\mathrm{t}}$ & \multicolumn{3}{c|}{ Critical value } \\
\hline & & $99 \%$ & $95 \%$ & $90 \%$ \\
\hline ADF & -2.91 & -0.44 & -1.06 & -1.31 \\
\hline SADF & $3.22^{+* *}$ & 1.06 & 0.60 & 0.34 \\
\hline RADF & $5.28^{* *+}$ & 2.21 & 1.45 & 1.05 \\
\hline GSADF & $5.95^{* *+}$ & 1.95 & 1.40 & 1.18 \\
\hline
\end{tabular}

*** indicates rejection of the normality assumption at the $1 \%$ significance level. $\mathrm{S}_{\mathrm{t}}=$ nominal exchange rate (rand per US dollar), $\mathrm{S}_{\mathrm{t}}-f_{\mathrm{t}}^{\mathrm{N}}$ and $\mathrm{S}_{\mathrm{t}}-f_{\mathrm{t}}^{\mathrm{T}}$ represent the ratios of the exchange rate to the non-traded and traded goods fundamentals, respectively. The initial window size $r_{0}$ is set as three years (36 observations). Critical values are obtained from Monte Carlo simulations with 5000 replications for the ADF, SADF and GSADF tests. Note that $* * *$ denotes statistical significance at the $1 \%$ level.

The result from the standard right-sided ADF test shows that the null hypothesis of no explosive behavior in the rand-dollar exchange rate should not be rejected at the conventional levels. The test statistic 2.91 is less than the critical value $(-0.44)$ at the 10 level 
of significance. However, Evans (1991) points out that the result from the standard right-sided ADF test may be biased especially in the presence of periodically collapsing bubbles. The SADF, RADF, and GSADF are designed to overcome this drawback. Indeed, the results from the SADF, RADF and GSADF tests indicate that the null hypothesis of no explosive behavior in the rand-dollar exchange rate should be rejected. The test statistics 3.30, 5.60 and 5.67, respectively, for SADF, RADF and GSADF are statically significant at the 1 percent level.

Table 3 presents the results from the ADF, SADF, RADF and GSADF procedures for exchange rate relative price of nontraded goods ratio $\left(\mathrm{s}_{\mathrm{t}}-f_{\mathrm{t}}^{\mathrm{N}}\right)$. Again, the right-sided standard ADF fail to reject the null hypothesis of no speculative bubbles in the relative prices of nontraded goods at the conventional levels. The test statistic $(-2.85)$ is less than the 10 percent value $(-1.31)$. However, the results from the SADF, RADF and GSADF tests reject the null hypothesis of no explosive behavior in the relative prices of nontraded goods. The computed test statistics 3.30, 5.60 and 5.67, respectively, for SADF, RADF and GSADF are statistically significant at the 1 percent level. These results indicate that the relative prices of nontraded goods play pivotal role in the explosive behavior exhibited by the nominal rand-dollar exchange rate.

Table 3. The ADF, SADF, RADF and GSADF tests for exchange rate-relative price of nontraded goods ratio

\begin{tabular}{|l|c|c|c|c|}
\hline \multicolumn{1}{|c|}{ Test } & $\mathrm{S}_{\mathrm{t}}-f_{\mathrm{t}}^{\mathrm{N}}$ & \multicolumn{3}{c|}{ Critical value } \\
\hline & & $99 \%$ & $95 \%$ & $90 \%$ \\
\hline ADF & -2.85 & -0.44 & -1.06 & -1.31 \\
\hline SADF & $3.30^{* * *}$ & 1.04 & 0.55 & 0.31 \\
\hline RADF & $5.60^{* * *}$ & 2.21 & 1.45 & 1.05 \\
\hline GSADF & $5.67^{* * *}$ & 1.83 & 1.41 & 1.17 \\
\hline
\end{tabular}

*** indicates rejection of the normality assumption at the $1 \%$ significance level. $\mathrm{s}_{\mathrm{t}}=$ the nominal exchange rate (rand per US dollar), $\mathrm{s}_{\mathrm{t}}-f_{\mathrm{t}}^{\mathrm{N}}$ and $\mathrm{s}_{\mathrm{t}}-f_{\mathrm{t}}^{\mathrm{T}}$ represent the ratios of the exchange rate to the non-traded and traded goods fundamentals, respectively. The initial window size $r_{0}$ is set as three years (36 observations). Critical values are obtained from Monte Carlo simulations with 5000 replications for the ADF, SADF and GSADF tests.

Table 4 shows the results from the ADF, SADF, RADF and GSADF tests for exchange rate relative price of traded goods ratio $\left(\mathrm{s}_{\mathrm{t}}-f_{\mathrm{t}}^{\mathrm{T}}\right)$. The result from the right-sided standard ADF fail to reject the null hypothesis of no speculative bubbles in the relative prices of traded goods at the 10 percent level of significance. The test statistic $(-2.97)$ is less than the 10 percent critical value
(-1.31). Conversely, the results from the SADF, RADF and GSADF tests reject the null hypothesis of no explosive behavior in the relative prices of traded goods. The test statistics 3.17, 5.02 and 5.11, respectively, for SADF, RADF and GSADF are statistically significant at the 1 percent level. These results indicate that the explosive behavior in the nominal rand-dollar exchange can be attributed to movements in the relative prices of traded goods between South Africa and the United States. Taken together, the results from the SADF, RADF and GSADF tests provide evidence of multiple bubbles in the nominal rand-dollar exchange rate; driven by both the relative prices of nontraded and traded goods between South Africa and the United States. This finding is inconsistent with the conventional wisdom, which stipulates that movements in relative price of nontraded goods alone are responsible for the fluctuations in the nominal exchanges rates.

Table 4. The ADF, SADF, RADF and GSADF tests for exchange rate-relative price of traded goods ratio

\begin{tabular}{|l|c|c|c|c|}
\hline \multicolumn{1}{|c|}{ Test } & $\mathrm{s}_{\mathrm{t}}-\boldsymbol{f}_{\mathrm{t}}^{\mathrm{T}}$ & \multicolumn{3}{c|}{ Critical value } \\
\hline & & $99 \%$ & $95 \%$ & $90 \%$ \\
\hline ADF & -2.97 & -0.44 & -1.06 & -1.31 \\
\hline SADF & $3.17^{*+*}$ & 1.04 & 0.55 & 0.31 \\
\hline RADF & $5.02^{* * *}$ & 2.21 & 1.45 & 1.05 \\
\hline GSADF & $5.11^{*+*}$ & 1.83 & 1.41 & 1.17 \\
\hline
\end{tabular}

*** indicates rejection of the normality assumption at the $1 \%$ significance level. $\mathrm{s}_{\mathrm{t}}=$ nominal exchange rate (rand per US dollar), $\mathrm{s}_{\mathrm{t}}-f_{\mathrm{t}}^{\mathrm{N}}$ and $\mathrm{s}_{\mathrm{t}}-f_{\mathrm{t}}^{\mathrm{T}}$ represent the ratios of the exchange rate to the non-traded and traded goods fundamentals, respectively. The initial window size $r_{0}$ is set as three years (36 observations). Critical values are obtained from Monte Carlo simulations with 5000 replications for the ADF, SADF and GSADF tests.

Having established the existence of multiple bubbles in the exchange rate series, the study next attempts to identify the locations of the bubble periods graphically using the SADF test. Figure 1 displays the plot of GSADF statistics for the nominal rand-dollar exchange rate. The graph shows evidence of multiple bubbles in the nominal exchange rate between South Africa and the United States. The first bubble occurred between July 1984 and May 1985. This period corresponds to the period of managed floating exchange rate system in South Africa. The second bubble occurred from October 2000 to December 2000 corresponding to the period of fully floating exchange rate system in South Africa. The third bubble occurred from August 2001 through November 2002. Again, this corresponds to the period of fully floating exchange rate regime in South Africa. 


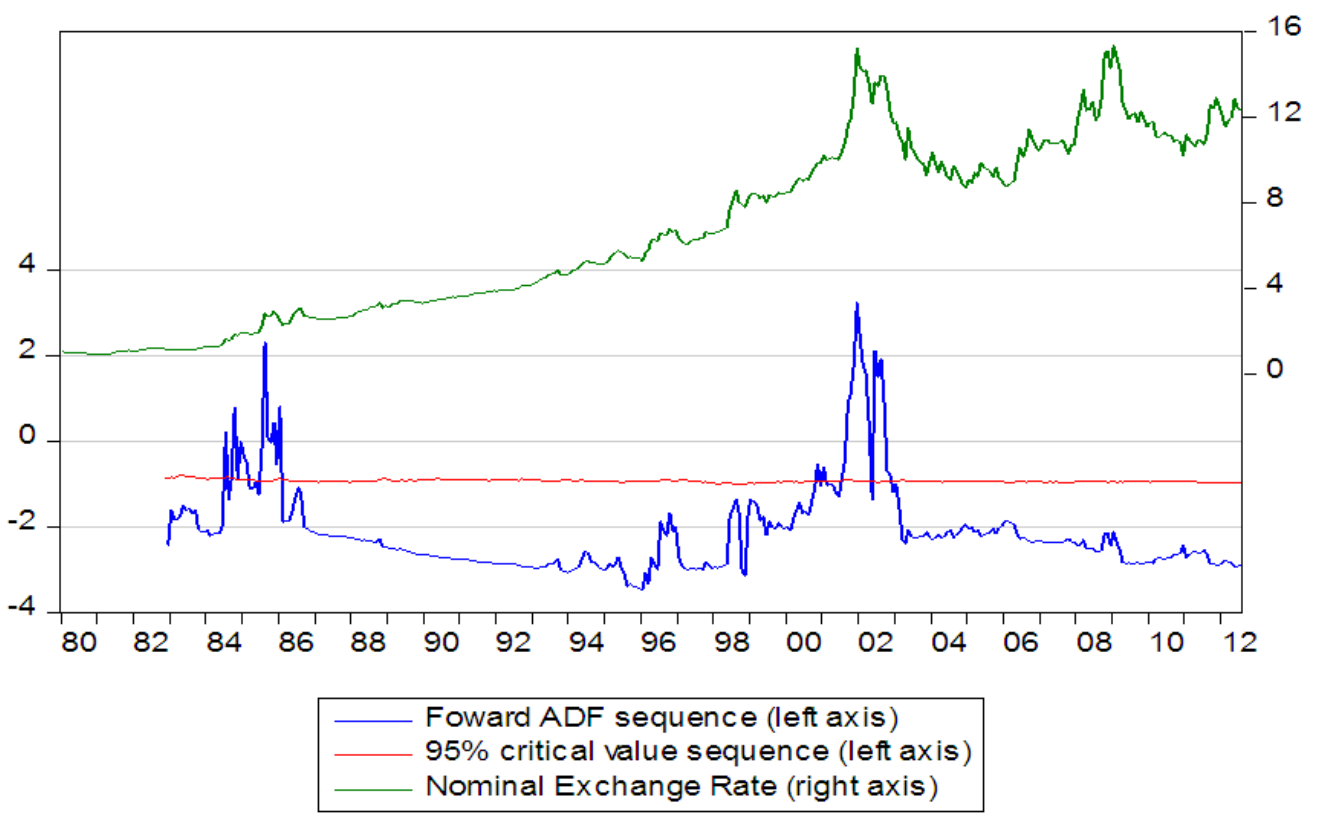

Fig. 1. SADF test for nominal rand-dollar exchange rate

Figure 2 displays graphically the results from the GSADF test for real exchange rate of nontraded goods $\left(\mathrm{s}_{\mathrm{t}}-f_{\mathrm{t}}^{\mathrm{N}}\right)$. The graph shows evidence of multiple bubbles with the first occurring be- tween October 1984 and March 1985. The was a brief bubble in January 2001. The last bubble started from September 2001 and collapsed in January 2003.

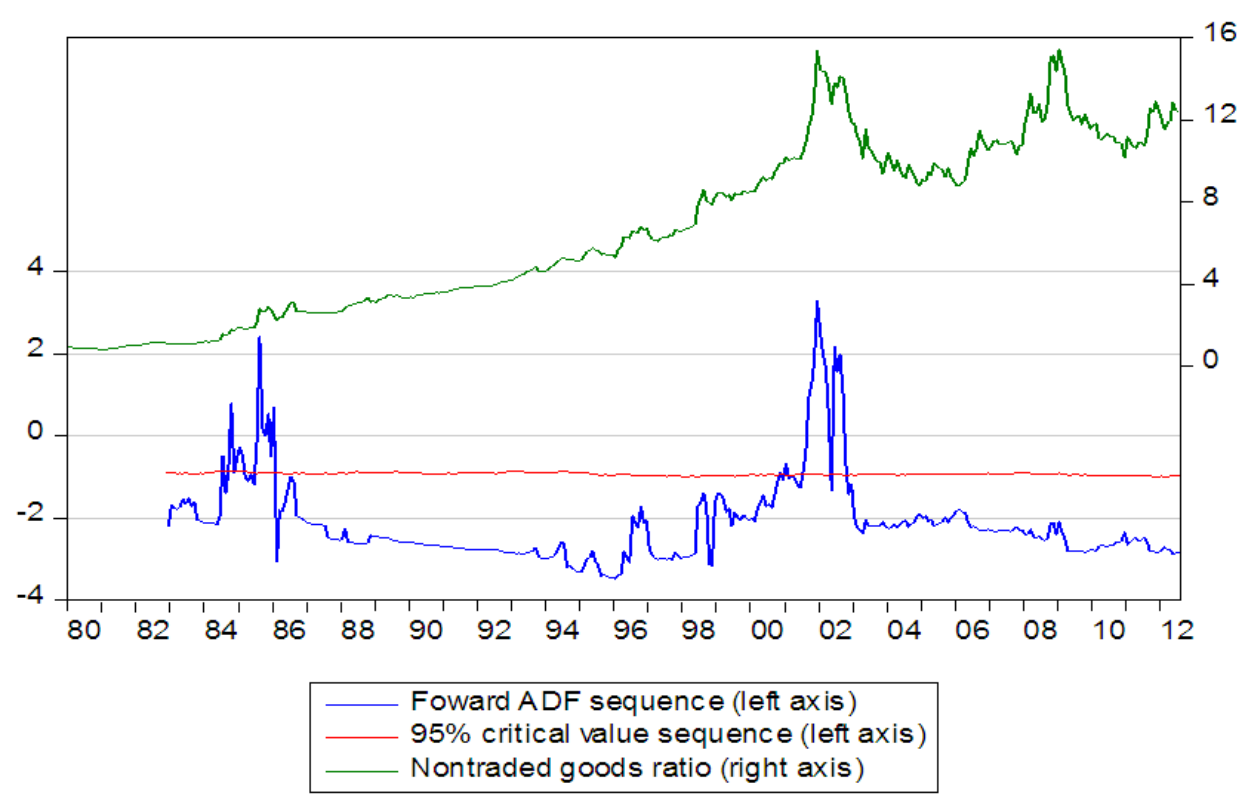

Fig. 2. SADF test for real exchange rate of non-traded goods

Figure 3 displays graphically the results from the GSADF test for real exchange rate of traded goods $\left(\mathrm{s}_{\mathrm{t}}-f_{\mathrm{t}}^{\mathrm{T}}\right)$. The graph provides evidence of multiple bubbles. The first bubble started in May 1984 and collapsed in March 1985. The second bubble started in July 1985 and ended in December 1985. The last bubble started in September of 2000 and collapsed January of 2003. From these graphs, we can infer that the explosive behavior in the nominal rand- dollar exchange rate is driven by the relative prices of nontraded and traded goods between the United States and South Africa. These results contradict the traditional theories of exchange rate, which posits that movements in the nominal exchange rate are driven by productivity differentials through the relative price of mainly non-traded goods (Balassa, 1964; Samuelson, 1964; Mendoza, 1991; Rebelo and Vegh, 1995; Stockman and Tesar, 1995). 


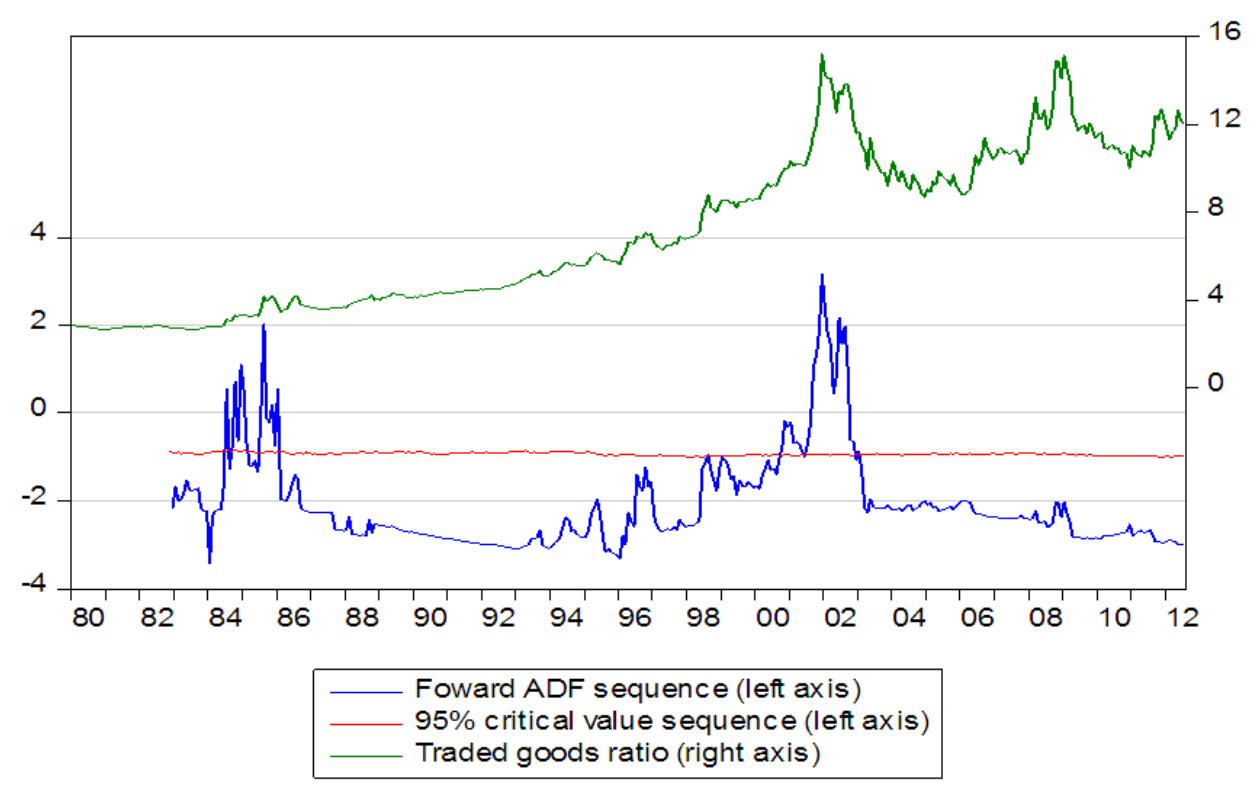

Fig. 3. SADF test for real exchange rate of traded goods

\section{Conclusion}

This study has examined the existence of rational speculative bubbles in the bilateral exchange rates between South Africa and the United States for the time period running from period January 1980 through July 2012. Specifically, the study used the sequential unit root tests including the right-tailed ADF tests, the SADF, RADF and the GSADF test to investigate the existence of rational speculative bubbles in the South African rand exchange rate. In the spirit of the study uses the relative prices of traded and non-traded goods as fundamentals for exchange rates (both constructed using the PPI, CPI and nominal exchange rates). The results from the standard right-sided ADF test failed to reject the null hypothesis of no explosiveness in the rand-dollar exchange rate. Results from the standard right-sided ADF procedure may be misleading, particularly in the presence of periodically collapsing bubbles. The results from the SADF, RADF and GSADF tests reject the null hypothesis of no speculative rational bubbles in the nominal exchange rate, relative prices of traded goods, and the relative prices of nontraded goods.

Graphical results show evidence of three speculative bubbles. The first bubble commenced in May 1984 and ended in May 1985. The second bubble started October 2000 and ended in December 2000. This particular bubble was brief and lasted for a total of two months. The third bubble lasted for about two years
(24 months). It started in January of 2001 and ended in January 2003. Taken together, the results from the SADF, RADF and GSADF tests suggest that the explosive behavior in the nominal rand-dollar exchange rate can be attributed to movements in both the relative prices of traded and nontraded goods. This finding is inconsistent with the conventional wisdom, which stipulates that movements in nominal exchange are mainly driven by the relative prices of nontraded goods.

The results from this study underscore the important roles the underlying fundamentals play in determining rational bubbles in asset prices. The investors should be cognizant of the existence of rational bubbles in the rand-dollar exchange rate. This knowledge will enable them to identify early warning signs of speculative bubble. It will also enable them to make informed decision by rationally selling their assets and, hence, adjusting the share prices toward their fair values leading to the attainment of market efficiency. The existence of rational speculative bubble may likely lead to the redistribution of wealth and, as such, can adversely affect the economy. It is, therefore, imperative for the policymakers to be aware of this possibility in order to formulate and implement appropriate intervention policies to mitigate the occurrence of speculative bubbles in the South African foreign exchange market.

\section{References}

1. Abhyankar, A., Copeland, L. S., and Wong, W. (1997). Uncovering nonlinear structure in real-time stock-market indexes: the S\&P 500, the DAX, the Nikkei 225, and the FTSE-100. Journal of Business \& Economic Statistics, 15(1), 1-14.

2. Bettendorf, T., and Chen, W. (2013). Are there bubbles in the Sterling-dollar exchange rate? New evidence from sequential ADF tests. Economics Letters, 120, 350-353.

3. Betts, C. M. and Timothy J. Kehoe. (2006). U.S. real exchange rate fluctuations and relative price fluctuations. Journal of Monetary Economics, 53, 1297-1326. 
4. Chun Jiang, Yi Wang, Tsangyao Chang \& Chi-Wei Su. (2015). Are there bubbles in Chinese RMB-dollar exchange rate? Evidence from generalized sup ADF tests, Applied Economics, 47(56), 6120-6135.

5. Edwards, S., and Yeyati, E. L. (2016). Flexible exchange rate as a shock absorber. NBER Working Paper No. 9867.

6. Evans, G. W. (1986). A test for speculative bubbles in the sterling-dollar exchange rate: 1981-84. American Economic Review, 76(4), 621-636.

7. Evans, G. W. (1991). Pitfalls in testing for explosive bubbles in asset prices. The American Economic Review, 81(4), 922-930.

8. Ghassen El Montasser, John Fry and Nicholas Apergis. (2016). Explosive bubbles in the US-China exchange rate? Evidence from right-tailed unit root tests, 9(1), 34-46.

9. Engel, Charles. (1999). Accounting for U.S. Real Exchange Rate Changes, Journal Political Economy, 107, $507-538$.

10. Hsieh, D. A. (1991). Chaos and nonlinear dynamics: application to financial markets. The Journal of Finance, 46(5), 1839-1877.

11. Jiang, Chun, Yi Wang, Tsangyao Chang \& Chi-Wei Su. (2015). Are there bubbles in Chinese RMB-dollar exchange rate? Evidence from generalized sup ADF tests, Applied Economics, 47(56), 6120-6135, DOI: 10.1080/00036846.2015.1064080.

12. Jirasakuldech, B., Emekter, R. and Went, P. (2006). Rational speculative bubbles and duration dependence in exchange rates: an analysis of five currencies, Applied Financial Economics, 16, 233-243.

13. Johansen, S. (1988) Statistical analysis of cointegrating vectors. Journal of Economics Dynamics and Control, 12 , 231-254.

14. Johansen, S., and Juselius, K. (1992). Testing structural hypothesis in a multivariate cointegration analysis of the PPP and UIP for the UK, Journal of Econometrics, 53, 211-244.

15. Kindelberger, C. M., and R. Aliber. (2005). Manias, Panics, and Crashes: A History of Financial Crises. $5^{\text {th }}$ edition Hoboken, NJ: Wiley.

16. Ghassen El Montasser, John Fry, \& Nicholas Apergis. (2016). Explosive bubbles in the US-China exchange rate? Evidence from right-tailed unit root tests, China Economic Journal, DOI: 10.1080/17538963.2015.1125591.

17. Obstfeld, M., and Rogoff, K. (1996). Foundations of International Macroeconomics. Cambridge: MIT Press.

18. Odhiambo, N. M. (2015). Exchange rate dynamics in South Africa: A review of past and present regimes. Economics, Management, and Financial Markets, 10(2), 77-95.

19. Phillips, P. C. B., Shi, S., and Yu, J. (2013). Testing for multiple bubbles. Singapore. Management University Working Paper No. 09-2011.

20. Phillips, P. C. B., Wu, Y., and Yu, J. (2011b). Explosive behavior in the 1990snasdaq: When did exuberance escalate asset values? International Economics Review, 52(1), 201-226.

21. Phillips, P. C. B., and Yu, J. (2011). Dating the timeline of financial bubbles during the subprime crisis. Quantitative Economics, 2(3), 455-491.

22. West, Kenneth D. (1987). A standard monetary model and the variability of the Deutschmark-Dollar exchange rate. Journal of International Economics, 23, 57-76.

23. Woo, Wing. (1987). Some evidence of speculative bubbles in the foreign markets. Journal of Money, Credit and Banking, 19, 499-514.

24. Wu, Yangru. (1995). Are there rational bubbles in foreign exchange markets? Evidence from an alternative test. Journal International Money and Finance, 14, 27-46.

25. Zhang, Y., and Yao, T. (2015). The bubble process of international crude oil futures prices: Empirical evidence from STAR model. International Journal Global Energy Issues, 38(1/2/3). 